\title{
Performance of sown species and weed ingress in new dairy pastures based on tall fescue and perennial ryegrass
}

\author{
K.N. Tozer ${ }^{1}$, E.M.K. Minnee ${ }^{2}$ and C.A. Cameron ${ }^{1}$ \\ ${ }^{1}$ AgResearch, Ruakura Research Centre, Hamilton 3240, New Zealand \\ ${ }^{2}$ DairyNZ, Private Bag 3221, Hamilton 3240, New Zealand \\ Corresponding author: katherine.tozer@agresearch.co.nz
}

\begin{abstract}
Poor performance of perennial ryegrass (Lolium perenne) and subsequent weed ingress reduces pasture productivity. Tall fescue (Schedonorus arundinaceus) is more droughttolerant than perennial ryegrass and may perform better in summer dry upper North Island environments, thus reducing weed ingress. To compare swards based on perennial ryegrass and tall fescue for performance of sown species and weed ingress, a replicated grazed plot study was established. Measurements were made every 3 months from May 2010 until May 2013. Percentage cover of sown species at the canopy surface was significantly higher in perennial ryegrass than tall fescue swards over 3 years. By the end of the third year, basal and canopy cover of unsown species in tall fescue swards reached $28 \%$ and $40 \%$ respectively compared with only $13 \%$ and $7 \%$ respectively in perennial ryegrass. Perennial ryegrass swards performed better and may provide a better option for keeping out weeds within the first 3 years of sowing.
\end{abstract}

Keywords $\mathrm{C}_{4}$ grasses, pasture performance, pasture persistence, weed invasion.

\section{INTRODUCTION}

In the upper North Island of New Zealand, there are concerns regarding pasture persistence (Kelly \& Smith 2011). While perennial ryegrass (Lolium perenne) provides a productive pasture base in this region, severe droughts and insect pests, such as black beetle (Heteronychus arator), Argentine stem weevil (Listronotus bonariensis) and grass grub (Costelytra zealandica), exacerbate perennial ryegrass mortality (Kelly \& Smith 2011; Zydenbos et al. 2011), which can lead to weed ingress. Tall fescue (Schedonorus arundinaceus) is less susceptible to a number of insects that attack perennial ryegrass and is more drought tolerant (Rollo et al. 1999); tall fescue pastures may therefore perform better in this region. In a controlled glasshouse study, moisture stress reduced growth and survival of perennial ryegrass compared with tall fescue, due to greater mortality of daughter tillers and reduction in stubble water soluble carbohydrate reserves in perennial ryegrass (Turner et al. 2012). However, there are few field-based data available on tall fescue performance and weed ingress in upper North Island dairy pastures as most studies have focused on perennial ryegrass. Recently, Tozer et al. (2012) studied the ingress of unsown grasses in tall fescue and tetraploid perennial ryegrass-based swards in Waikato. 
While useful for understanding summer-active grass weed ingress, the focus of that study was on monitoring survival and seed production of the hand-sown $\mathrm{C}_{4}$ grasses rather than monitoring natural ingress of weeds.

Poor performance of sown species may be characterised by the loss of particular desirable traits in sown species (e.g. the phenotypic expression of high yielding characteristics), the loss of production from other, unrelated causes (e.g. an increase in undesirable weed species) or the loss of plants from the sward (Parsons et al. 2011). Assessments of basal cover (i.e. the ground surface area occupied by the plant base) enable plant losses through time to be documented and are a useful measure for monitoring performance with respect to plant survival. For example, Virgona \& Bowcher (2000) used basal cover to assess the persistence of tall fescue and three other perennial grass species over a 2-year period. Assessments of canopy cover have also been used to monitor changes in pasture vegetation and ingress of weeds (Setterfield et al. 2005; Goslee et al. 2009).

A replicated field plot study was therefore established under rotational grazing to monitor the performance of sown species and ingress of unsown species in tall fescue and perennial ryegrass swards, based on assessments of basal cover and canopy cover over a 3-year period. The hypothesis tested was that tall fescue-based swards would perform better (with a higher basal and canopy cover) than the perennial ryegrassbased swards, and have fewer weeds.

\section{METHODS}

\section{Site establishment}

A site was established at DairyNZ's Scott Farm, Hamilton, New Zealand $\left(37^{\circ} 47^{\prime}\right.$ S, $175^{\circ} 19^{\prime}$ E) on a Matangi silt loam (Stiles \& Singleton 1997) in autumn 2010, as part of a larger study to compare the performance of a range of pasture types on pasture and milk production (Woodward et al. 2013). Site establishment began with soil testing in mid-February 2010. Soil pH was 5.8, Olsen P: 37 ppm, K: 5 MAF QT units and Sulphate-S: $15 \mathrm{ppm}$. The existing sward was removed using two applications of $2.2 \mathrm{~kg}$ ai/ha glyphosate
(Glyphosate 510SL) applied on 22 February and 16 March, along with an application of $9 \mathrm{~mm}$ liquid effluent $(63 \mathrm{~kg} \mathrm{~N} / \mathrm{ha}, 9 \mathrm{~kg} \mathrm{P} / \mathrm{ha}$ and $26 \mathrm{~kg}$ $\mathrm{K} / \mathrm{ha}$ ). After ploughing, $2 \mathrm{t} / \mathrm{ha}$ lime and $635 \mathrm{~kg} / \mathrm{ha}$ maintenance fertiliser (50P: 58S: $18 \mathrm{Mg}$ : $122 \mathrm{Ca}$ : $20 \mathrm{Na}$ ) was applied. The site was then power harrowed and rolled. Plots (with dimensions of $9 \times 7 \mathrm{~m}$ ) were drilled to a depth of approximately $1 \mathrm{~cm}$ with a range of seed mixtures and the seed bed rolled on 30 March 2010. While a total of 14 treatments was established in 42 plots, only two treatments in six plots are presented here.

The two treatments comprised (i) perennial ryegrass + white clover (Trifolium repens) + red clover (T. pratense) and (ii) tall fescue + white clover + red clover. Perennial ryegrass (cv. One50 AR1) was sown at a rate of $23 \mathrm{~kg} / \mathrm{ha}$, tall fescue (cv. Advance) at $30 \mathrm{~kg} / \mathrm{ha}$, white clover (cv. Kopu II) at $3 \mathrm{~kg} / \mathrm{ha}$ and red clover (cv. Colenso) at $4 \mathrm{~kg} / \mathrm{ha}$. The grazed field plots were established in a completely randomised design consisting of two pasture treatments and three replicates.

Annual rainfall at Scott Farm in 2010, 2011, 2012 and 2013 was $1384,1485,1277$ and $1184 \mathrm{~mm}$ respectively, compared to the long term average annual rainfall for this area of $1156 \mathrm{~mm}$ (30 year average, 1975-2004, Ruakura weather station). Rainfall over summer (December-February) was lower than the long-term average of $259 \mathrm{~mm}$ in one of the three years (2010-2011: $334 \mathrm{~mm}$, 2011-2012: $376 \mathrm{~mm}, 2012-2013: 151 \mathrm{~mm}$ ).

\section{Site management}

Maintenance fertiliser was applied each autumn to the whole site based on soil test results from the previous spring (annual applications of $\mathrm{P}=35 \mathrm{~kg} / \mathrm{ha} ; \mathrm{K}=117 \mathrm{~kg} / \mathrm{ha} ; \mathrm{S}=50 \mathrm{~kg} / \mathrm{ha}$ (mean application over 3 years)). Nitrogen fertiliser (urea) was applied after each grazing at a rate of $25 \mathrm{~kg} \mathrm{~N} /$ ha per application with an annual maximum of $200 \mathrm{~kg} \mathrm{~N} / \mathrm{ha}$. No herbicide was applied to the site after sowing.

Each plot was fenced and individually grazed by three mixed-age Holstein-Friesian dairy cows when forage cover had reached 2800-3000 kg DM/ha as determined by weekly visual assessment. Grazing was observed and cows removed once the pasture height reached $4-5 \mathrm{~cm}$ 
(1500-1600 kg DM/ha), as per recommended DairyNZ grazing guidelines (Lee et al. 2011). Plots were grazed six times in 2010 (between the first grazing at the end of March and the end of December), 10 times in each of 2011 and 2012 and twice in 2013 prior to the final assessment on 20 May 2013.

\section{Measurements}

The percentage of basal and canopy cover was determined every 3 months between 19 May 2010 and 20 May 2013 using a point technique described by Edwards et al. (1996).

During each assessment, basal and canopy cover were monitored in four permanent quadrats randomly positioned in each plot to determine changes in botanical composition (i.e. persistence of sown species and weed ingress). Each $30 \times 30 \mathrm{~cm}$ square quadrat was divided into 36 cells, each of dimensions $5 \times 5 \mathrm{~cm}$. This equated to a total of 144 cells per plot. Accurate quadrat placement was aided by four coloured weed mat pins positioned at the corners of each quadrat. The pins protruded $0.5 \mathrm{~cm}$ above the soil surface and remained in the ground for the duration of the study.

The presence and identity of basal cover, and presence and identity of the canopy of plants were recorded for each cell in each quadrat. To determine the canopy cover species, a tapered $1.0 \mathrm{~cm}$ diameter cylindrical apparatus was lowered within the centre of each cell and the first species that contacted the centre point of the apparatus was recorded. The canopy was then pushed aside using this apparatus to identify the basal cover of the species closest to the centre of each cell (i.e. shoots emerging from the soil). If no plant base was present at the tip of the apparatus, basal cover was recorded as 'bare ground'.

\section{Statistical analyses}

Sown species (sown grass + sown legumes), unsown species (weed) and bare ground data were averaged over the four quadrats for each plot. Data were analysed by analysis of variance using GenStat, 16th edition. A repeated measures analysis of variance using the GreenhouseGeisser correction including all times was performed. Data were angular-transformed when necessary to equalize the variance to better meet the normality assumptions of the analysis. Arithmetic treatment means are presented but statistical inferences are based on transformed data when transformations were undertaken.

\section{RESULTS}

There was a consistent trend of higher total sown species basal and canopy cover in perennial ryegrass than tall fescue swards. This was statistically significant for canopy cover in November 2011, August 2012 and May 2013 (Table 1). When averaged over all years (in the repeated measures analysis), total sown species canopy cover was greater in the ryegrass than tall fescue swards ( $94 \%$ versus $76 \%, \mathrm{P}=0.007$, Table 1). This was due to the higher sown grass component in perennial ryegrass than tall fescue swards. This equated to a sown grass basal cover of $33 \%$ versus $25 \%$ and sown grass canopy cover $81 \%$ versus $54 \%$ in perennial ryegrass and tall fescue swards respectively when averaged over the 3-year assessment period (Figure 1). Legume basal cover (white + red clover) was similar for tall fescue and perennial ryegrass swards (averaging $13 \%$ over the experimental period), but legume canopy cover was greater in tall fescue than perennial ryegrass swards (averaging 22\% versus $13 \%$ over the assessment period, Figure 1).

Conversely, there was a consistent trend for higher weed basal and canopy cover in tall fescue than perennial ryegrass swards, which was statistically significant on four occasions (Table 1). When averaged over all years (in the repeated measures analysis), weed basal and canopy cover was also greater in tall fescue than ryegrass swards (canopy cover: $18 \%$ versus 3\% respectively, $\mathrm{P}=0.043$; basal cover: $12 \%$ versus $5 \%$ respectively, $\mathrm{P}=0.045$, Table 1). In tall fescue swards, weed basal and canopy cover varied between 4 and $40 \%$, depending on the month and year (Table 1). However, in perennial ryegrass swards, weed basal and canopy cover remained below 13\% (Table 1).

Broadleaf weed basal and canopy cover remained low, averaging 3\% and $2 \%$ respectively in perennial ryegrass swards and $6 \%$ for both basal and canopy cover in tall fescue swards. 
Table 1 Percent basal and canopy cover of sown species (grass + clover), weeds and bare ground, in perennial ryegrass + white clover + red clover $(R G)$ and tall fescue + white clover + red clover swards (TF) grazed by dairy cattle. Swards were assessed every 3 months from May 2010 to May 2013. ${ }^{*}: \mathrm{P} \leq 0.05 ;{ }^{* *}: \mathrm{P} \leq 0.01 ;{ }^{* *}: \mathrm{P} \leq 0.001$. SED: standard error of difference of the means.

\begin{tabular}{|c|c|c|c|c|c|c|}
\hline & \multicolumn{3}{|c|}{ Basal cover } & \multicolumn{3}{|c|}{ Canopy cover } \\
\hline & RG & TF & SED & RG & TF & SED \\
\hline \multicolumn{7}{|l|}{ Sown species } \\
\hline 2010 May & 40 & 38 & 4.3 & 97 & 73 & 7.9 \\
\hline Aug & 42 & 40 & 2.4 & 99 & 92 & 2.1 \\
\hline Dec & 53 & 45 & 4.0 & 99 & 86 & 5.9 \\
\hline 2011 Feb & 60 & 41 & 8.4 & 98 & 79 & 5.7 \\
\hline May & 42 & 41 & 6.0 & 94 & 91 & 0.8 \\
\hline Aug & 45 & 40 & 5.2 & 99 & 84 & 5.7 \\
\hline Nov & 44 & 39 & 5.9 & 97 & 79 & $1.8^{*}$ \\
\hline 2012 Feb & 44 & 41 & 5.8 & 87 & 68 & 7.9 \\
\hline May & 44 & 41 & 3.8 & 98 & 81 & 8.0 \\
\hline Aug & 37 & 37 & 1.0 & 90 & 62 & $2.6^{* *}$ \\
\hline Nov & 34 & 35 & 2.4 & 94 & 78 & 7.4 \\
\hline 2013 Feb & 49 & 42 & 13.2 & 77 & 55 & 9.6 \\
\hline May & 32 & 27 & 4.3 & 89 & 55 & $4.2^{*}$ \\
\hline Average $^{1}$ & 44 & 39 & 1.2 & 94 & 76 & $1.5^{\star *}$ \\
\hline \multicolumn{7}{|l|}{ Weeds } \\
\hline 2010 May & 6 & 19 & 4.0 & 3 & 25 & 9.3 \\
\hline Aug & 10 & 33 & 6.4 & 1 & 8 & 2.1 \\
\hline Dec & 0 & 6 & $0.5^{\star *}$ & 0 & 8 & 3.4 \\
\hline 2011 Feb & 0 & 4 & 1.1 & 2 & 8 & 2.1 \\
\hline May & 1 & 10 & 3.5 & 2 & 9 & 1.5 \\
\hline Aug & 5 & 8 & 4.7 & 1 & 16 & 5.7 \\
\hline Nov & 4 & 6 & 4.1 & 1 & 18 & $3.5^{*}$ \\
\hline 2012 Feb & 1 & 6 & 1.4 & 1 & 12 & $1.6^{*}$ \\
\hline May & 3 & 8 & 3.1 & 1 & 19 & 8.1 \\
\hline Aug & 9 & 12 & 2.8 & 4 & 26 & 8.1 \\
\hline Nov & 3 & 6 & 3.1 & 5 & 22 & 6.5 \\
\hline 2013 Feb & 3 & 7 & 1.5 & 7 & 19 & 4.1 \\
\hline May & 13 & 28 & 9.5 & 7 & 40 & $6.1^{*}$ \\
\hline Average & 5 & 12 & $1.6^{\star}$ & 3 & 18 & $3.2^{*}$ \\
\hline \multicolumn{7}{|l|}{ Bare ground $^{2}$} \\
\hline 2010 May & 53 & 43 & 6.8 & 0 & 3 & 1.4 \\
\hline Aug & 48 & 27 & $4.3^{*}$ & 0 & 0 & 0.2 \\
\hline Dec & 47 & 49 & 3.5 & 0 & 5 & 4.8 \\
\hline $2011 \mathrm{Feb}$ & 40 & 54 & 7.5 & 0 & 13 & 5.0 \\
\hline May & 56 & 49 & 5.8 & 3 & 0 & 2.0 \\
\hline Aug & 50 & 52 & 5.3 & 0 & 0 & 0.0 \\
\hline Nov & 52 & 55 & 3.0 & 2 & 3 & 3.4 \\
\hline 2012 Feb & 55 & 53 & 6.8 & 13 & 21 & 9.5 \\
\hline May & 54 & 52 & 1.2 & 0 & 0 & 0.2 \\
\hline Aug & 55 & 51 & 3.0 & 6 & 12 & 9.9 \\
\hline Nov & 62 & 59 & 2.4 & 1 & 0 & 0.9 \\
\hline $2013 \mathrm{Feb}$ & 49 & 51 & 12.9 & 16 & 26 & 13.3 \\
\hline May & 55 & 45 & 10.6 & 5 & 6 & 4.5 \\
\hline
\end{tabular}

${ }^{1}$ The average was obtained from a repeated measures analysis of variance over the 3 -year period. ${ }^{2}$ The average for bare ground from the repeated measures analysis of variance is not shown due to significant interactions between the month and sward type (RG versus TF). 
a

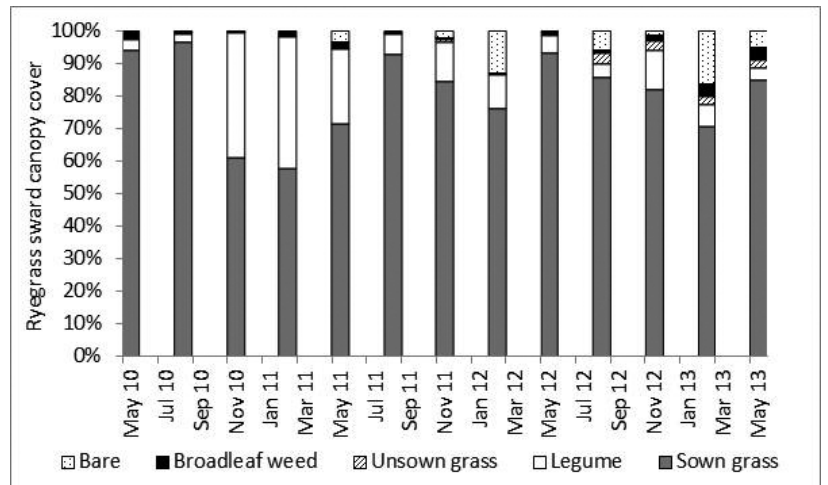

b

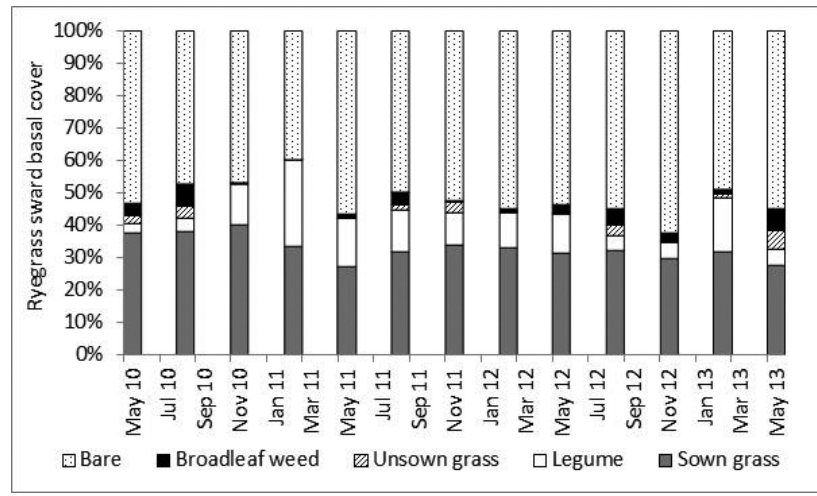

c

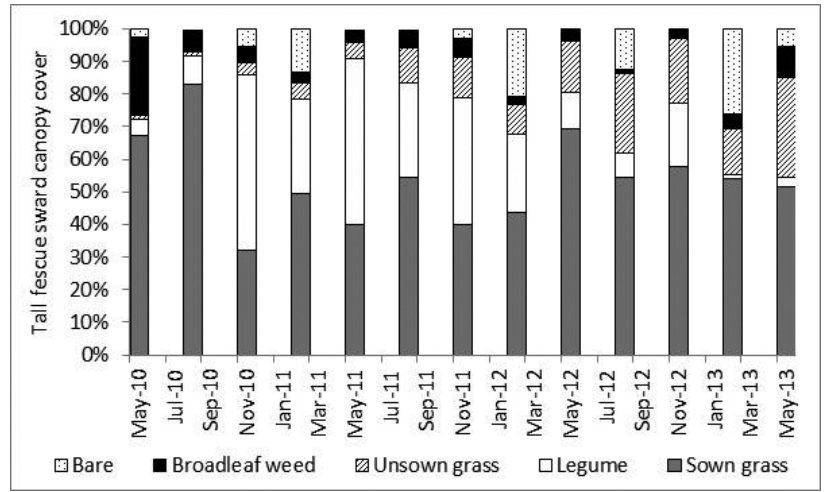

d

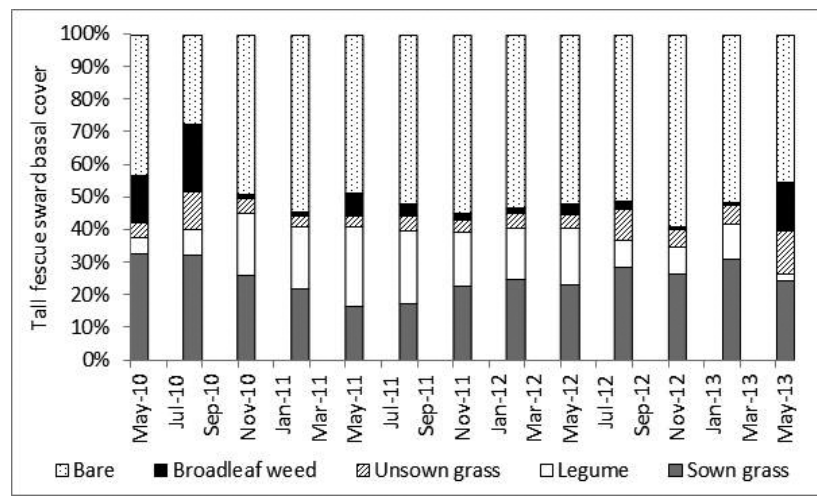

Figure 1 Canopy ( $1 \mathrm{a} \& 1 \mathrm{c}$ ) and basal (1b \& $1 d$ ) cover of perennial ryegrass-based swards ( $1 \mathrm{a} \& 1 \mathrm{~b}$ ) and tall fescue-based swards (1c \& 1d) grazed by dairy cattle. Swards were assessed mid-month, every 3 months over a 3-year period from May 2010 until May 2013. 
The most prevalent broadleaf weeds included dandelion (Taraxacum officinale), chickweed (Stellaria media), hawksbeard (Crepis capillaries), purple cudweed (Gamochaeta coarctata) and dock (Rumexspp.). Basal cover of unsown grasses remained low in perennial ryegrass and tall fescue swards, averaging $2 \%$ and $6 \%$ in perennial ryegrass and tall fescue swards respectively (averaged over all assessments). Canopy cover of unsown grasses was also low in perennial ryegrass swards (averaging 1\%) but comprised up to $31 \%$ in tall fescue swards in May 2013 (with an average of $12 \%$ over all assessments). The most dominant unsown grass in the tall fescue swards was perennial ryegrass, with annual poa (Poa annua) and summer grass (Digitaria sanguinalis) present to a lesser extent in both sward types. The basal cover of perennial ryegrass in the tall fescue swards averaged 3\% while in the canopy it averaged 9\% (which equated to 3\% in the first year, $11 \%$ in the second and $16 \%$ in the third).

The frequency of bare ground at the soil surface was higher in perennial ryegrass than tall fescue swards in August 2010 (48 versus 27\%, $\mathrm{P}<0.01)$. The percentage of gaps in the canopy (i.e. no canopy cover) was consistently lower in perennial ryegrass than tall fescue swards but the differences were not statistically significant (Table 1).

\section{DISCUSSION}

Tall fescue swards did not perform as well as perennial ryegrass swards. This is indicated by (1) the lower canopy cover of sown species in tall fescue than perennial ryegrass swards, and (2) the greater basal and canopy cover of weeds in tall fescue than perennial ryegrass swards.

The greater legume canopy cover in tall fescue than perennial ryegrass swards is consistent with published literature (Tozer et al. 2012). The higher legume content would improve pasture quality, which would have benefits for livestock performance and milk production (Harris et al. 1998).

A likely reason for the greater legume content is the slower establishment of tall fescue than perennial ryegrass (Easton et al. 1994), which would enhance the establishment of legumes and other companion species. Slower establishment of tall fescue in this study was supported by the consistent trend of a greater canopy cover of sown perennial ryegrass than sown tall fescue during the first few months after sowing (Figure 1).

There was also greater weed ingress in tall fescue swards, which comprised $40 \%$ of the sward canopy in May 2013. This was despite the previously mentioned evidence for tall fescue being more drought tolerant than perennial ryegrass and despite the occurrence of a summer drought during the study period. The greater weed ingress may also be explained by the slower establishment of tall fescue and its more open canopy structure, which favours both desirable species such as legumes, as well as weedy species such as hawksbeard and purple cudweed. While perennial ryegrass was one of the most frequently occurring unsown grass species (averaging 9\% of the sward canopy), farmers do not consider perennial ryegrass as desirable in tall fescue swards, as it will compete with tall fescue and may reduce tall fescue performance. While the ground cover of perennial ryegrass in tall fescue swards remained low (approximately 3\%), its ability to compete vigorously within tall fescue swards was demonstrated by the increase in canopy cover of perennial ryegrass over the 3 -year period, from $3 \%$ to $16 \%$.

Observations made looking down at a pasture give a view that is quite different to what is occurring at the soil surface. Thus, dry matter accumulation may not always give an observer a true picture of plant survival. Figures $1 \mathrm{a}$ and $1 \mathrm{c}$ demonstrate how the sward surface appearance can fluctuate greatly over the year, which was influenced by the time of assessment relative to the regrowth cycle (i.e. days since grazing). The basal cover fluctuated less which is to be expected given that it is an indicator of plant presence rather than biomass accumulation (Figure $1 \mathrm{~b}$ \& 1d). Basal cover data also highlight the large amount of bare ground present in a pasture, which averaged approximately 50\% (averaged over pasture type and assessment date). This is space that can be colonised by weeds, as occurred to a greater extent in the tall fescue swards where there was a trend towards lower sown species 
basal cover and a higher basal and canopy cover of weeds than in the perennial ryegrass swards.

In conclusion, based on the first 3 years of this study, it is suggested that perennial ryegrass rather than tall fescue be sown in Waikato dairy pastures, if the goal is to maximise the content of sown species and reduce the ingress of unsown species. Monitoring is on-going, to determine if the trend of better performance of perennial ryegrass continues, given the frequent summer droughts.

\section{ACKNOWLEDGEMENTS}

Thanks to DairyNZ scientists and technicians for establishing and maintaining the field site at which this study was undertaken (Sharon Woodward, Tiffany McAllister) and to MPI for provision of funding (SFF 09-088). We are appreciative of assistance with data collection and entry from Mike Trolove, Claire Dowsett, Rose Greenfield and Carol Fletcher.

\section{REFERENCES}

Easton HS, Lee CK, Fitzgerald RD 1994. Tall fescue in Australia and New Zealand. New Zealand Journal of Agricultural Research 37: 405-417.

Edwards GR, Parsons AJ, Newman JA, Wright IA 1996. The spatial pattern of vegetation in cut and grazed grass white clover pastures. Grass and Forage Science 51: 219-231.

Goslee SC, Sanderson MA, Gonet J 2009. No persistent changes in pasture vegetation or seed bank composition after fallowing. Agronomy Journal 101: 1168-1174.

Harris SL, Auldist MJ, Clark DA, Jansen EB 1998. Effect of white clover content in the diet on herbage intake, milk production and milk composition of New Zealand dairy cows housed indoors. Journal of Dairy Research 65: 389-400.

Kelly S, Smith E 2011. Pasture renewal in the Waikato and Bay of Plenty regions: An overview of farmer practice, experience and attitudes. Pasture Persistence - Grassland Research and Practice Series 15: 21-24.

Lee J, Hedley P, Roche J 2011. Grazing management guidelines for optimal pasture growth and quality. DairyNZ Technical Series, Issue 5. Pp. 6-10.
Parsons AJ, Edwards GR, Newton PCD, Chapman DF, Caradus JR, Rasmussen S, Rowarth JS 2011. Past lessons and future prospects: plant breeding for yield and persistence in cooltemperate pastures. Grass and Forage Science 66: 153-172.

Rollo MD, Sheath GW, Slay MWA, Knight TL, Judd TG, Thomson NA 1999. Tall fescue and chicory for increased summer forage production. Proceedings of the New Zealand Grassland Association 60: 249-253.

Setterfield SA, Douglas MM, Hutley LB, Welch MA 2005. Effects of canopy cover and ground disturbance on establishment of an invasive grass in an Australia savanna. Biotropica 37: 25-31.

Stiles S, Singleton P 1997. The distribution of soils on the AgResearch farm at Newstead, Hamilton. AgResearch Internal Report. 60 p.

Tozer KN, Minneé EMK, Cameron CA 2012. Resistance of New Zealand dairy pastures to ingress of summer-active annual grass weeds. Crop \& Pasture Science 63: 1026-1033.

Turner LR, Holloway-Phillips MM, Rawnsley RP, Donaghy DJ, Pembleton KG 2012. The morphological and physiological responses of perennial ryegrass (Lolium perenne L.), cocksfoot (Dactylis glomerata L.) and tall fescue (Festuca arundinacea Schreb.; syn. Schedonorus phoenix Scop.) to variable water availability. Grass and Forage Science 67: 507-518.

Virgona JM, Bowcher A 2000. Effects of grazing interval on basal cover of four perennial grasses in a summer-dry environment. Australian Journal of Experimental Agriculture 40: 299-311.

Woodward SL, Waugh CD, Roach CG, Fynn D, Phillips J 2013. Are diverse species mixtures better pastures for dairy farming? Proceedings of the New Zealand Grassland Association 75: 79-84.

Zydenbos SM, Barratt BIP, Bell NL, Ferguson CM, Gerard PJ, McNeill MR, Phillips CB, Townsend RJ, Jackson TA 2011. The impact of insect pests on pasture persistence and their interrelationship with biotic and abiotic factors. Pasture Persistence - Grassland Research and Practice Series 15: 109-118. 